\title{
Thinking of Biko in the Time of Covid-19
}

\author{
Michael Cloete \\ https://orcid.org/0000-0003-1751-9784 \\ University of South Africa \\ mcloete99@gmail.com
}

\section{Abstract}

The Covid-19 pandemic has presented serious questions; not only of a medicalscientific nature, but of a deeply philosophical nature as well. Often, when faced with the unknown - whether in the form of an environmental catastrophe or a general health threat-finding effective ways to overcome our fear of the unknown yields important clues regarding not only the nature of our selfunderstanding as human beings, but also our all-too-human perceptions of Other(s). While the impact of the Covid-19 pandemic has been especially harsh on people living in conditions of extreme poverty and material deprivation, our collective response has (predictably) proceeded from a position that privileges the interests and lifestyles of the rich, the well-resourced and the politically connected, in a manner that sadly confirms the biblical prophecy: the poor will always be among you. This essay seeks to examine the impact of Covid-19 in South Africa. Its analytic focus proceeds from the perspective of Steve Biko's conception of Black Consciousness philosophy. It seeks to argue that Biko's humanist project of liberation offers important insights that can assist us in the normative quest for a society "with a more human face."

Keywords: Covid-19 pandemic; Steve Biko; Black Consciousness Philosophy; humanism; white supremacy

\section{Introduction}

The immense scale of suffering and death associated with pandemics, epidemics and plagues has been a constant feature of human history. Human vulnerability and susceptibility to various forms of bacterial and viral infections have often resulted in the development and spread of various contagious and infectious diseases. The epistemic nature of quite a number of these diseases continues to baffle leading practitioners and researchers in the field of medical science. While the discovery of a cure or an effective vaccine may have been found for some of these medical conditions, there are many others-such as the common cold and HIV/AIDS, to mention but two-whose

\section{UNISA $\cong$}




\section{Cloete}

etiological nature and biological complexity we are still trying to understand. The Covid-19 pandemic is the most recent arrival on the growing list of incurable diseases that the global community will have to contend with in the foreseeable future. While the development and spread of deadly viruses invariably challenge established epistemic assumptions in the field of medical science and related practices in the healthcare profession, it has also had significant ethical-political implications; its impact has been especially harsh on people living in conditions of extreme poverty and material deprivation.

Conditions of extreme poverty and material deprivation are normally viewed in the wealthy, industrialised countries of the Global North as the logical and inevitable outcome of the "progressive" economic policies of global capitalism. In the Global South, however, these conditions must be viewed through the historical lens of European colonial-modernity and its associated project of capitalist expansionism. In this context, the justification for the untold suffering wrought in the wake of the European colonial project of capitalist expansionism has been systematically developed into a "science" in which the idea of "difference" was foregrounded as a priori epistemic category for distinguishing the "fully human" from the "less-than human" being. This racist "scientific" account of non-European "difference" has thus provided the epistemic condition of possibility of the (problematic) universalisation of the Eurocentric paradigm of what it means to be a human being-ontologically, morally, and intellectually. In this problematic paradigm, the capacity for rational thought and reflection is identified as the distinctive characteristic of a (real) human being; this characteristic has been denied to the non-European "savages" who live "outside and beyond" the light of human reason. In the present context of neoliberal global capitalism, however, it is the poor who have been condemned to a zone of non-humanbeing, where the light of reason cannot penetrate the ontological obscurity of their nonhuman presence in the world (Fanon 2017, 2).

Like most countries across the world, post-apartheid South Africa has experienced great suffering as well as a tragic loss of human life in large numbers because of the Covid19 pandemic. While the suffering and death associated with the spread of the coronavirus have tragically contributed to a renewed sense of human vulnerability, it has also succeeded in shedding new light on the continued perpetuation and deterioration of the socio-economic conditions of "ordinary" people, especially the poor, the vulnerable, the homeless, the elderly and disabled. The enduring perception among them is that nothing significant has really changed in their lives since the "miracle" of 1994. For them, Covid-19 is just another agonising challenge in an endless cycle of poverty and abandonment. Michael Moloufi, a lifelong resident of Snake Park, in Soweto, captures the deep sense of anguish experienced daily not only by his fellowresidents, but also by so many people living in South Africa: 


\section{Cloete}

Many people are dying of Covid-19 in Snake Park. Almost every day we are burying people. ... We are scared for our lives. ... I don't know how else to explain it. We really don't know how we are going to do this. ${ }^{1}$

Jaqueline Matlola, also a resident of Snake Park - and a mother of four-expresses a sense of abandonment that resonates undoubtedly with so many others when she says:

I am always stressed: for myself, for my kids, and for the community. We don't know what is going to happen tomorrow, so I say: "Only God knows." They [the relevant government officials have to date not visited the community of Snake Park to "talk about the virus"]. They don't come. They don't care about us ...2

The overwhelming sense of abandonment, especially among the poor, living in black communities and townships across post-apartheid South Africa, is reminiscent of the famous statement by the South African Students Organisation (SASO), one of the original representative voices of Black Consciousness, namely, "Black Man, you Are on your Own!" (Biko 1987, 91). Not even the country-wide implementation of programmes of much-needed medical support and social relief by various government agencies-in conjunction with various non-profit organisations (NPOs) - has done much to alleviate the general feeling among the poor and the vulnerable that they have been abandoned, and that they are "on their own."

The rapid spread of coronavirus infection has (sadly) coincided with the rapid spread of corruption, as more and more officials in government as well as certain sectors of civil society have (unashamedly) welcomed the Covid-19 pandemic as an opportunity for self-enrichment; to the complete disregard of the needs of the poor. When considered from the perspective of Steve Biko's philosophy of Black Consciousness - and the associated project of black liberation - the current display of selfish greed and moral insensitivity to the needs of the poor, attests to a "[yearning] for the comfort of white society" (Biko 1987, 28). In this context, the (human) right to life has sadly been neglected and overlooked, while the capitalist's right to prosper in the time of Covid-19 has triumphed.

In this essay, I reflect broadly on some of the implications of this yearning for the "comfort of white society" in relation to: 1) Biko's dream of a liberated society with "a more human face" $(1987,98)$; and 2) the relevance and significance of that dream for Covid-19 South Africa.

\section{Thinking in Dark Times}

Political philosopher, Hannah Arendt (1968), devoted much time reflecting on the historical phenomenon of evil as a moral-political problem. In this regard, she was particularly interested in the tendency and relative ease with which human beings tend

1 Mail and Guardian 2020

2 Mail and Guardian 2020 


\section{Cloete}

to succumb to the power of "evil." She claims that the human potential for evil is best revealed during times of political crises, especially under regimes characterised by a totalitarian dictatorship. Arendt's reflections in this regard led her to conclude that the failure to identify the social symptoms of moral-political evil is a direct consequence of an epistemic-ethical failure that compromises the rational capacity to recognise and judge evil for what it really is. In the place of rational judgment, we tend to create excuses and rationalisations to obscure the social causes and to soften the impact of evil. Arendt likens the human potential for evil - and the associated forms of complicity- to a condition of epistemic "darkness." She argues, furthermore, that the condition of epistemic "darkness" undermines the possibility for creating a society in which the voices of the victims of political totalitarianism and racism are truly heard and publicly acknowledged in the struggle for justice (Arendt 1958). In response to Arendt's theory of human evil, Brad Evans has called for the need to create the relevant "space[s] where we encounter the pain of others and truly reflect on its significance to a shared human community" (cited in Giroux 2018 307). Roger Berkowitz (2010, 3) accounts for Arendt's epistemology of thinking in dark times as follows:

For Arendt, dark times are not limited to the tragedies of the twentieth century; they are not even a rarity in the history of the world. Darkness, as she would have us understand it, does not name the genocides, purges, and hunger of a specific era. Instead, darkness refers to the way these horrors appear in public discourse and yet remain hidden. As Arendt observes, the tragedies ... [are] not shrouded in secrecy and mystery, yet they [are] darkened by the "highly efficient talk and double-talk of nearly all official representatives who, without interruption and in many ingenious variations, [explain] away unpleasant facts and justified concerns."

In recent months, the outbreak of Covid-19 has certainly dominated public discourse in post-apartheid South Africa. Grounded normatively in a neoliberal economic paradigm that espouses the values of individual freedom and autonomy in a "free" market system, this public discourse has been mainly focused on an ethics that speaks to the economic freedom and rights of the (upper) middle class, bourgeoisie and corporate world. In this context, where the entrenched economic interests of power and privilege have (almost by default) mediated the impact of the Covid-19, suffering experienced in the povertystricken, (predominantly) black communities and townships, has been reduced to a heath crisis in which the underlying economic injustices of the past are simply ignored. The neoliberal version of the plight of the poor has "darkened" the nature of their suffering; it forecloses the possibility of an appropriate historical perspective that will enable a dialogical-epistemic condition of black liberation, one that will effectively deconstruct ahistorical epistemological paradigms that celebrate "progress" (especially in the spheres of capitalist economics and technology) in South Africa, to the disregard of its historical conditions of possibility not only in the past, but also in the present (Terreblanche 2002, 25-49).

The responsibility for dealing with Covid-19 in South Africa has devolved mainly on experts in the medical and business communities, whose advice thus far to government 


\section{Cloete}

has been to contain the spread of the coronavirus by ensuring an adequate supply of food parcels as well as protective masks until an effective vaccine has been developed. These supplies have been dispensed under conditions of lockdown and other related stay-at-home restrictions, as well as social distancing regulations that have been particularly hard on the poor and the homeless. During this period of "waiting for a cure" the commercial and personal interests of business and other professional people have been given the necessary space to operate, where possible, either from their homes, or (under certain specified restrictions) in the public sphere as part of the "new" normal.

This "new" normal has, however, not only created the conditions for the pursuit of commercial interest and profit during Covid-19; it has also, rather tragically, created conditions that have enabled the spread of political corruption and the cynical pursuit of economic opportunities for purposes of personal advantage and financial gain. It is a cruel manifestation of human greed that has structurally sustained the neoliberal pandemic of global capitalism. Beneath the glossy surface of global capitalism and its most recent ally, Covid-19, lies an inhuman ontological-political condition of darkness, strongly reminiscent of the existential predicament of the prisoners, so vividly portrayed by Plato (1961) in his famous Allegory of the Cave (514a-521a). In this context, the possibility of liberation comes in the form of an epistemic illumination, metaphorically associated by Plato with the sun as the source of light and life. Plato's allegory was specifically designed to emphasise a fundamental moral idea; the possibility of "life" and the alleviation of human suffering in its most naked forms require the light of human reason. From this perspective, we could argue that to deny the light of human reason to certain human beings (women, children, African people, the enslaved) is tantamount to denying their humanity (Ramose 2002, 1-8). The light of human reason, together with the right and freedom to make sense of - and give meaning to - the varied experiences of human beings, articulated from an epistemic standpoint that is culturally embedded within their own specific traditions of thought, is the first (foundational) condition for the possibility of "philosophy." The present political climate of post-apartheid South Africa, epistemically darkened by the neoliberal paradigm of "free" market rationality and neoliberal capitalist fundamentalism, needs the illuminating presence of a philosophy that is capable of dealing with the reductionistic discourses that currently characterise economic discourse in South Africa, where the views of "experts" are valued more highly than the opinions of ordinary people (Moodley 2008, 267-268). Biko's philosophy of Black Consciousness speaks to that need.

The radical humanism at the core of Biko's philosophy of Black Consciousness has much to teach us about the suffering of the poor. Sceptical of both the Marxist-socialist as well as the liberal critiques of apartheid South Africa, Biko opted instead for an existential-ontological hermeneutic that emphasises the need for a "spiritual" understanding of black suffering, one that that reveals the inadequacy of an exclusively materialist approach; for him, neither the market-friendly approach of liberal capitalism nor the anti-free-market approach of Marxist-socialism is capable of doing justice to the "spiritual" dimensions of black poverty (Biko 1987, 28). This does not imply, however, 
that Biko was any less concerned about the material (socio-economic) dimensions of black poverty; he merely seeks to stress that in order to understand the full impact of material poverty, one would also have to take into account its impact on the human potential for spiritual growth under conditions of psychological and political oppression. Speaking specifically from the perspective of black oppression in South Africa, Biko identifies the problem of black inferiority and dependency in relation to white South Africans as a major challenge. He writes: "What Black Consciousness seeks to do is to produce at the output end of the process real black people who do not regard themselves as appendages to white society" (Biko 1987, 51). To live as "appendages to white society" is tantamount to black people being complicit in their own "spiritual poverty" (Biko 1987, 28) — a condition much worse than material deprivation. Biko writes:

Material want is bad enough, but coupled with spiritual poverty it kills. And this latter effect is probably the one that creates mountains of obstacles in the normal course of the emancipation of the black people. (Biko 1987, 28)

Biko's focus on the "spiritual" dimensions of black poverty provides the normative point of departure for contemplating the possibility of black liberation in a radically transformed, humane society. His deep concern about the suffering of black people, in particular, analysed within the moral-political framework of Black Consciousness philosophy, offers some valuable insights of great relevance today as we try to come to terms with the devastating impact of Covid-19 in post-apartheid South Africa. Like Arendt, Biko believes that spiritual darkness is a necessary consequence of a failure to confront the evil of political totalitarianism as it unfolds with devastating effect in a system which routinely obscures the abuse of political and economic power, and which routinely indulges in problematic pronouncements that seek to justify evil as something "normal" in society. In this regard, it is rather interesting to note that coming to terms with Covid-19 requires the creation and acceptance of a "new normal" in which the very conditions that have structurally and systemically enabled the perpetuation of historical injustice, have once again been invoked in Covid-19 South Africa to help legitimate the neoliberal-capitalist theology of wealth accumulation and self-enrichment with a view to overcoming the "black problem."

Neo-apartheid - in the form of a (recreated) social division between a (minority) class, consisting of a rich, privileged, bourgeois black-white elite, on the one hand, hovering (dialectically) over a class of mostly black people, on the other hand, living in appalling conditions of extreme poverty and material deprivation - certainly recalls the "evil" that Arendt (1968) speaks of. More appropriately, it also recalls Biko's telling observation, "Apartheid is obviously evil. Nothing can justify the arrogant assumption that a clique of foreigners has the right to decide on the lives of a majority" (Biko 1987, 27).

\section{How Does it Feel to be a Problem?}

It took a while for the Covid-19 pandemic to reach the shores of South Africa from its place of origin in Wuhan, China. Like most other countries across the globe, South 


\section{Cloete}

Africa chose initially to reassure itself of its own safety from infection on the basis of its considerable geographical distance (of just over 11000 kilometres) from the Chinese mainland. At this time, the majority of South Africans had more pressing issues to worry about; a faltering economy, poverty and the escalating trends of unemployment, an upsurge in violent crime (especially against women and children), a lack of service delivery on the part of incompetent municipal authorities, widespread corruption in government circles, deteriorating conditions in public schools and public healthcare facilities - to mention but a few. From this perspective, the arrival of Covid-19 has merely served to reinforce the general perception among the majority of South Africans, especially the poor, that they are certainly not a preferential option of the state. The dramatic upsurge in corruption reached alarming proportions as an elite class of politically connected government officials - as well other selected custodians of social grants within an ever-growing network of non-profit organisations - opted instead to enrich themselves, at the expense of the poor, the sick and the needy. According to the Argentine liberation philosopher, Enrique Dussel, in a world driven by the economic imperatives of global capitalism, the poor (as the majority of humankind) find themselves marginalised and excluded, ontologically and ethically. Dussel (2013, xxii) argues that this tragic situation calls for the introduction of a liberatory "ethics of life" that will restore a transcendent sense of human dignity and human solidarity as a first principle. It is the general failure to recognise and acknowledge the humanity of the poor as a prior condition for the acknowledgement of our own humanity that makes them a "problem."

In the context of post-apartheid South Africa, poor people living in townships, on the streets and in the outskirts of our cities have become "a problem to be fixed." Reports in the news and social media of immigrants and refugees (predominantly from other African countries) being victimised in disturbing incidents of xenophobic attacks, have become all too familiar. Efforts by local government administrations to relocate and resettle them in "more secure" places of safety, beyond the established social milieu and economic hubs of our major cities, attest to a humanitarian crisis that is causing social tension not only within the communities of the local population, but also between the South African government and the various African states from which these refugees have fled. Not even the churches situated in major cities such as Cape Town and Johannesburg (that had historically given shelter to the homeless and the socially uprooted) have proved themselves capable of providing much-needed shelter to the homeless and the socially uprooted during Covid-19. ${ }^{3}$ It would appear that in these tragic circumstances, the Covid-19 pandemic has merely offered local government and its supporters a much-needed excuse to get rid of the "foreigners" desperately searching for a better life for themselves and their families in post-apartheid South Africa (Neocosmos 2010). 


\section{Cloete}

In addition to the problem of "foreigners," Covid-19 has provided a much-needed excuse to deal with the "problem" of violent crime in our major cities, especially in the black townships. In the city of Cape Town, for example, the problem of "Coloured" gangsterism on the Cape Flats, in addition to the problem of homeless children and adults on the streets, has reinforced the public perception that poverty and crime constitute an "ethnic-racial" problem - a problem that is endemic to "Coloured" communities. Given this perception, the custodians of the city have approached the socio-economic challenges presented by homeless children and adults, on the one hand, and violent crime, on the other, as a "problem to be fixed." Homeless adults and children are normally perceived to be street-smart criminals, conducting a reign of terror against local (mainly white) residents, living in the wealthier suburbs and working mainly in the Central Business District of Cape Town, as well as unsuspecting tourists from abroad who visit our shores in good faith (Samara 2011).

The local authorities' response to the problem of violence and crime has often been one of violence; the presence of the South African police (as well as soldiers of the South African National Defence Force) in these townships has often been accompanied by various forms of brutality, aimed at "containing" the "violent, criminal" (pre)dispositions of the communities under surveillance. ${ }^{4}$

Tony Roshan Samara $(2011,2)$ has highlighted the plight of street children and homeless adults as follows:

Street children and homeless or destitute adults in the downtown have been routinely demonized by local press, downtown business interest, and city authorities for years ... because of the crimes they allegedly commit and the fear they induce in the more affluent classes with whom they share this contested space. ... Some of the street people and their advocates view the increase in harassment [by police] as linked to a growing intolerance for both adults and children living on the streets in the wake of a "new quality of life" bylaw approved by the city council ... [This] "nuisance law" includes, among other things, prohibitions on begging, washing clothes in public, and failing to move along when ordered to do so by a security officer, prohibitions which many feel were specifically crafted to criminalize behaviors associated with the urban poor. (Samara 2011, 2)

It has been fairly commonplace among anti-racist social theorists and political philosophers, engaged critically with the problem of white supremacy and black oppression, to denaturalise and demystify the ideological trappings of white supremacist thinking and practices by focusing on the specific historical origins and circumstancesas well as the social nature — of black suffering and oppression. W.E.B. Du Bois (2007), for example, has problematised the hegemonic racist epistemology in which black people are viewed as a "problem." He argues that the primary purpose of this

4 https://www.atlanticcouncil.org/blogs/africasource/pandemic-policing-south-africas-mostvulnerable-face-a-sharp-increase-in-police-related-brutality. 


\section{Cloete}

epistemology is to justify racist assumptions of white superiority and black inferiority as the "natural" order of things in an anti-black, white supremacist society.

In response to the problem of white supremacy, Du Bois has issued a direct challenge to the black person in the form of a question, How does it feel to be a problem? (Du Bois 2007, 7). The purpose of this question is twofold: firstly, it seeks to deconstruct and dismantle the foundational assumptions of white supremacist thinking; secondly (more importantly), it seeks to reveal the extent to which black people themselves have been complicit in their own oppression. The internalisation of the white value system as the normative foundation for the possibility of being-human-in-the-world has led to a crisis of identity in the collective psyche of black people, as a direct consequence of the unrelenting criminalisation of the ontological presence of black people in the world. The courageous response recently displayed by members of the Black Lives Matter movement - and black communities, in general — in the face of police brutality and the killing of black youth in the United States, is but the latest instalment in the racist narrative of dehumanisation of black people as well as the deeply entrenched (institutionalised) perception that black people are a "problem."

In this context, the development of a different sense of selfhood, one that calls into question and thus challenges the dehumanisation of the black person, has given rise to an "inner conflict." This conflict finds expression within a "double consciousness" as the psychological substratum in which the self-defeating (human) struggle for ontological-ethical wholeness unfolds as the precondition of the black person's assertion of self-identity. According to Du Bois:

[The] sense of always looking at one's self through the eyes of others, of measuring one's soul by the tape of a world that looks on in amused contempt and pity. One ever feels his twoness - an American, a Negro; two souls, two thoughts, two unreconciled strivings; two warring ideals in one dark body, whose dogged strength alone keeps it from being torn asunder. (Du Bois 2007, 8)

For Du Bois, as for many other philosophers engaged in the problematic of black subjectivity, it is the hegemonic impact of the internalisation of white normativity that accounts primarily for the black person's problematic validation of the normative foundations of the very system that has historically called into question the black person's humanity in the first place.

Steve Biko's philosophy of Black Consciousness reflects a form of critique that is similar in nature to that of Du Bois. In his critical engagement with colonial-apartheid South Africa in general-and the problem of white supremacy and white racism in particular - the problem of black subjectivity is fundamental. Biko compares the ontological nature of a black person's life to that of someone living in "an empty, obliging shell" (Biko 1987, 28-29). From this perspective, the black person "looks with awe at the white power structure and accepts what he regards as the inevitable position"” (Biko 1987, 28). Biko writes, furthermore: 


\section{Cloete}

In the privacy of his [sic] toilet [the black person's] face twists in silent condemnation of white society but brightens up in sheepish obedience as he comes running out to his master's impatient call. ... He yearns for the comfort of white society and makes him blame himself for not having been "educated" enough to warrant such luxury. (Biko 1987, 28)

For Biko, overcoming the yearning for the "comfort of white society" represents the first important step towards black liberation; it is the precondition for the possibility of light and life in a transformed society with a "more human face" (Biko 1987, 98). At the root of Biko's appropriation of Black Consciousness philosophy is a vision of a society radically transformed and completely liberated from the ideological trappings of white normativity. His critique of post-colonial apartheid South Africa is an attempt not only to acknowledge the reality of the black person's complicity in his or her own oppression and suffering, but also for allowing "evil [to] reign supreme in the country of his birth" (Biko 1987, 29). For Biko, overcoming the yearning for the comfort of white society (whether in its liberal or Marxist-socialist form) requires the creation of an "inward-looking process." Biko $(1987,29)$ thus requires, first of all, a process of black self-reflection and black self-knowledge - without which freedom will remain a mere rhetorical gesture. Consequently, the obfuscation of the self-interested pursuit of political and economic power will undermine the possibility of (historical) justice. And, as a further consequence, the poor will always be among us. The poor thus continues to be a "problem to be fixed" in the land of their birth. For Biko, this problem is especially acute whenever the impoverished, oppressed black person fails to realise that:

[The] most potent weapon in the hands of the oppressor is the mind of the oppressed. Once the latter has been so effectively manipulated and controlled by the oppressor as to make the oppressed believe that he is a liability to the white man, then there will be nothing the oppressed can do that will really scare the powerful masters. (Biko 1987, 68)

\section{The Politics and Economics of Corruption}

Post-apartheid South Africa is currently experiencing the negative effects of a neoliberal capitalist political economy that is, tragically, out of sync with the basic needs of "ordinary" people living within its borders. Deep levels of poverty, material deprivation and the struggle to survive in the face of ever-deepening levels of socio-economic inequality have become the order of the day. The South African government's response to the problem of poverty and material inequality has been the introduction of certain programmes of economic reform, aimed at creating a more enabling economic climate that will (hopefully) ensure the creation not only of an oligarchy that serves the interests of black business and corporate sectors under the banner of Black Economic Empowerment (BEE), but also enable the creation of job opportunities for the poor, within a more "racially" inclusive economy (Marais 2001, 240-243). While the project of BEE has certainly succeeded in producing significant levels of affluence as well as the related opportunities for further self-advancement among the black elite, the 


\section{Cloete}

anticipated benefits for the poor, in the form of "trickle-down" effects, have sadly not materialised. As a result, more and more people are suffering the consequences of poverty and unemployment; more and more people have become dependent on social grants from government in order to survive (Mbeki 2009, 84-89).

It is interesting to note that, despite the creation of a more "racially" integrated economy, the phenomenon of excessive wealth is still regarded among the majority of black South Africans as the exclusive privilege of white people. As Neville Alexander points out:

[W]orking class youth in the townships ... often refer to an obviously wealthy black person as umlungu (white man or white woman), thereby recognizing the class shift that has taken place for a tiny section of the formerly oppressed people but expressing this in racial terms, the only discourse of social hierarchy that they knew. (Alexander 2013, 49)

Alexander's point regarding the association of material wealth with umlungu carries even more weight when aligned with Biko's observation regarding the black person who "yearns for the comfort of white society" $(1987,28)$. For historical reasons, many black South Africans, have found it nigh-impossible to disentangle the issue of class from the issue of race, despite the "miracle" of 1994 (Terreblanche 2002, 137-138).

Current thinking, which suggests that the solution to the problem of poverty and material inequality lies in the adoption of a self-centred, individualistic pursuit of material wealth within the parameters of a neoliberal capitalist political economy, is extremely problematic. This is the case because the very system that offers hope to the individual (as entrepreneur and consumer) also (simultaneously) produces unemployment and poverty on a large scale, as its inevitable structural consequences. Notwithstanding these negative consequences, the assumptive logic at the core of neoliberal capitalism that will have us believe that a "free" market system is our only hope of overcoming poverty, has simply not been challenged, or challenged effectively enough. Neither the "new" social movements abroad, nor the establishment of similar anti-capitalist organisations in South Africa, such as the Landless People's Movement (LPM), ${ }^{5}$ and more recently, the C-19 People's Coalition (C19PC), has succeeded in disrupting the core values that constitute the normative foundations of the capitalist political economy. ${ }^{6}$

Human labour is a creative process that stems from the ontological core of the human experience and the related human struggle for survival. From this perspective, human labour constitutes a process of universal significance that is grounded in the human being's right to life. The human being's right to life is a right that (ontologically and ethically) demands universal acknowledgment as the condition of possibility of the political economy. Within the current context of global capitalism, however, the person as a labourer is unable to reap the benefits of his or her labour, while the threat of

5 https://www.sahistory.org.za/article/landless-peoples-movement.

6 http://roape.net/2020/09/08/hunger-anger-and-a-new-social-movement-in-south-africa/. 


\section{Cloete}

"alienation" emanating from the large-scale misappropriation of "surplus value" (in the form of wealth accumulation and profit-making) by the "owners" of the production process, remains a constant structural feature. Poverty, therefore, will always be a structural consequence of the capitalist political economy (Marx 1978, 70-81). Given the brutal nature of socio-economic alienation, the complex moral significance of "traditional" human behaviour in the marketplace is reduced to the level of being mere consumers in society, one-dimensional men and women (Marcuse 1964). We tend to lose sight of the historical fact that "the market" has always - in addition to providing the opportunity for the economic exchange of goods - been the "place" where human beings (as social creatures) gather to (re-)establish human contact and human solidarity with other people. The marketplace has been traditionally accepted as a means of social interaction, valued more highly than the value of money and profit-making (Gray 1998, 1-21). The artificial creation of various "needs" for the consumer in capitalist society is thus predicated on the foundational assumption that human greed, combined with the aggressive-competitive instinct of survival in the marketplace, is "by nature" a good thing.

From this perspective, materialist greed, corruption and violent crime (currently so rife in Covid-19 South Africa), are symptomatic manifestations of the same disease: capitalism. In this context, political reform ("from above") works closely in tandem with an economics that appeals to an economic theology, grounded in an unshakeable belief in the intrinsic superiority and inevitability of capitalism as a progressive, civilisational force of universal significance (Saul 2005, 15-16). In the South African historical context of colonial conquest and white supremacy, the approach that advocates political reform through the economic prism of neoliberal capitalism, fails to address the devastating impact that this system has had on the humanity of the indigenous, historically conquered African and enslaved people. The valorisation of an economics that is inspired by a consumerist and profit-making ethos promotes an individualist ethics of human agency on the one hand, and a "business" ethics of transnational corporate autonomy, on the other hand, as the distinctive hallmarks of a "superior" human rationality.

The assumptive logic of the "free" market system operates in direct violation of the humanist foundations that inspire the normative frames of reference emanating from the indigenous, cultural traditions of the historically conquered African people. Within the various ethical renditions of African humanism, the human right to life, conceptualised within a context of inter-human solidarity, cooperation and mutual support, compassion and reciprocity, stands out as the first commandment within the African moral community (Gyekye 2002, 297-312). The right to life is valued above everything else; its intrinsic (universal) value precedes, ontologically and ethically, the formation of all economic systems (Ramose 2002, 2; Ramose 1999, 135-140). Given this humanist perspective, the capitalist elevation, valorisation and sanctification of money is a blatant violation of the right to life. In this system. we fail to "see" the Other (the economically excluded and marginalised). In this system, money has been endowed with a 


\section{Cloete}

transcendent significance-equal in status to that of the wine (symbolising the blood) and the bread (symbolising the body) of Christ, celebrated at the Last Supper and commemorated by Christian communities across the world. ${ }^{7}$ As Mogobe Ramose, argues:

Money has become the "god" towards which everything must move and before whom everyone must submit. In this sense we wish to borrow and endorse the insight that the invention of money is the original sin of economics. (Ramose 1999, 131)

One could argue that the widespread corruption associated with the arrival of Covid-19 in South Africa is a consequence of the "original sin of economics"; the invention of money as a means of power, self-enrichment and control over the lives of others is the root of most evils ravaging society today. The recent proliferation in post-apartheid South Africa of shady deals, nepotism and cover-ups associated with "state capture" (Pauw 2017) are but the latest episodes in a long history of corruption. The theft and consequent "ownership" of African land and mineral resources, the destruction of the precolonial economic systems of the indigenous African people for the sake of a capitalist economy, in which the enslaved and disenfranchised black people were forced into positions of subservience and dependency, represent important sub-texts of a master-narrative that is grounded (metaphysically and historically) in the "original sin of economics." The "C" in Covid-19 that has become synonymous with the " $\mathrm{C}$ " in Corruption, merely casts new light on an unethical political economy that originated some three and half centuries ago.

\section{Biko's Dream}

According to Biko (1987, 69), black liberation requires the prior possibility of an "inward-looking process" - the purpose of which is the development of the possibility of (critical) self-reflection. Biko envisages this process as one that unfolds in an intersubjective, dialogical context that will enable black people to confront the psychological impact of anti-black racism and white supremacy. This process seeks to foreground the historical-political experiences of black oppression and suffering on the humanity of black people, conceptualised as a subjective experience. Biko's point of departure, in this regard, is reminiscent of Frantz Fanon's humanist project, insofar as for each of them, the question of "man" as a universal subject is problematised within the general context of white supremacy and black oppression, while - at the same time - emphasising the subjective (psychological) dimensions of that experience. The "inward-looking processes" that Biko adumbrates constitute a point of departure similar in intent to Fanon's call for a social ontology that seeks to establish a universalist conceptual framework; one that is capable of capturing the black experience under white supremacy, as well as indicating the relevant possibilities of black "disalienation" (Fanon 2017, 1-7). Given this perspective, Hussein Abdilahi Bulhan (1985, vii) correctly points out that for Fanon, "The disaster of the man of color ... lies in the fact

7 See, for example, The Gospel of Matthew, 26: 17-30. 
that he was enslaved ... the disaster and inhumanity of the white man lie in the fact that somewhere he has killed man."

Biko defends a universalist humanism similar in intent to that of Fanon. For Biko (1987, 90), the black subject's quest for a 'true humanity, where power politics will have no place" requires the self-consciousness appropriation of a black identity that recognises its dialectical entanglement within the "white man's world." This dietetically acquired sense of blackness seeks not only to problematise the question of "man," as traditionally conceptualised within the philosophical framework of Western thought; it also suggests the possibility for reframing the question of humanity in an entirely different manner. It is a "quest for a true humanity" (Biko 1987, 87-98).

The subjective dimension of the Black Consciousness struggle has often been a target of criticism on the grounds that its tendency to "psychologise" the struggle, undermines the more activist-practical imperatives that are required to resist and overcome the harsh structural-systemic nature of white supremacy (Gibson 2008, 129-155). This form of critique subscribes to a rather restrictive view of "the political"; however; it fails to recognise that the fundamental question in Black Consciousness philosophy is the question of humanity, not as an abstract idea, but as a concrete and practical challenge. From this perspective, Strini Moodle, for example, a leading voice of the Black Consciousness Movement (BCM), accounts for the nature of the black struggle as follows:

[It] has to be based primarily on ... the fact that 70 percent of [black oppression] ... is fixed mentally in the oppressed.... So that you have to devise a philosophy that can break the chains of that psychological oppression. You've got to first free them [psychologically]. You've got to reintroduce in them the fact that they are human beings. (Moodley, cited in Mngxitama, Alexander, and Gibson 2008, 267-268)

Beyond the psychological dimensions of black oppression, Biko focuses on the possibility of remembering (in the Platonic sense) certain fundamental ideas associated with the foundational idea of humanism, as it finds expression in various African cultural traditions of thought. His primary objective is to create the relevant epistemic space(s) that will enable and ensure that the voices of the African people can truly be heard, not only as the victims of white supremacy, but also as culturally embodied people, fully mindful of the fact that their historical presence in "South Africa" precedes that of the European settlers by centuries (Elphick and Malherbe 1989, 3).

For Biko, black liberation would be meaningless without first engaging with the idea of humanism. His preferred approach in this regard is to proceed from a position that is grounded in the epistemic-ethical traditions of African humanist thinking (Biko 1987, 40-47). His rejection of liberal anti-apartheid politics should, therefore, also be construed from the perspective of his Africanist-humanist stance (Biko 1987, 8-16). He was of the view that liberal anti-apartheid politics, essentially motivated by a sense of (white), is too deeply entrenched in the systemic trappings of white privilege to be able 


\section{Cloete}

to understand, let alone speak on behalf of the black experience. By advancing a political model of white-black "racial" integration in a white-black integrated capitalist economy as an alternative apartheid South Africa, the liberal position simply leaves intact the historical economic-material basis of black oppression (Biko 1987, 90). On a much deeper level, the liberal dialectics of "racial" integration is predicated, systemically and ethically, on the negation of the African person as a human being (Biko 1987, 89-90).

Challenging the ethos of a Eurocentrically-driven historiographical tradition, in which political identity coincides with being-white in South Africa (or, alternatively, with wanting to-be-white in South Africa), Biko (1987, 40-47) posits a counter-narrative of African humanism, created, preserved and critically transmitted intergenerationally over many centuries within the indigenous cultural traditions and histories of precolonial African thought. The reclamation of values and knowledge systems of the indigenous people of Africa, "battered nearly out of shape in the great collision between indigenous values and the Anglo-Boer culture" (Biko 1987, 92) is an important step in the process of black liberation. From this perspective, the historically oppressed are urged to become "[their] own authorities rather than wait to be interpreted by others" (Biko 1987, 52). He claims, furthermore:

I am sufficiently proud to believe that under a normal situation, Africans can comfortably stay with people of other cultures and be able to contribute to the joint cultures of the communities they have joined. (Biko 1987, 45)

It is important to recognise that Biko's project is not targeted only at white supremacy and white racism as the exclusive products of white South Africans. He is equally critical of the assumption that being-non-white is synonymous with being-black in South Africa. For Biko, to yield to the identity of non-whiteness is to be complicit in one's own dehumanisation; it perpetuates and justifies white normativity as the exclusive frame for determining the degree of one's humanity. Biko, therefore, claims that "non-whiteness" is the "aspiration to whiteness" as the condition for being-humanin-the-world (Biko 1987, 49). Blackness, on the other hand, predicated on the foundational idea of African humanism, stems from the realisation that one's own humanity is predicated on the prior possibility of acknowledging and respecting the humanity of the Other. Herein lies the moral substance of Biko's dream of black liberation. It is a leap of faith rather than a "rationally" defined political agenda. In this dream, Biko adumbrates a society that values the idea of humanity above everything else. The epistemic vagueness that has accompanied Biko's dream ultimately stems from a humanist perspective that forecloses the possibility of meaningful change initiated exclusively from pre-ordained ideological blueprints imposed "from above." This would betray not only the democratic ethos in which his dream of liberation has been conceived, but also the voices of African people seeking historical and social justice. 


\section{Conclusion}

Biko's philosophy of Black Consciousness represents an important chapter in the political-moral experience of black oppression and black liberation. While the political situation that Biko addressed during his time has undoubtedly changed in many respects, "apartheid" as a formal political system is now a thing of the past; 1994 witnessed the introduction of a post-apartheid South Africa, based on the principles of a constitutional democracy; however, there still remains many important historical issues of justice that have yet to be addressed within the "new" South Africa. In this regard, Biko's philosophical message of humanism - in the context of black solidarity-reinforces the idea that the question of humanity (and the struggle for social justice) can only be adequately addressed when we are finally capable of "sensing" the ethical presence of something compellingly "sacred" in the Other's ontological presence in the world.

His message of humanism and black solidarity is especially relevant today as we struggle to come to terms with the devastating impact of the Covid-19 pandemic. While the Covid-19 pandemic has offered us great insight into the divisive and antagonistic nature of social relations in post-apartheid South Africa, it has also offered us glimpses of a more human society. Biko's dream of a society with a "more human face" will continue to be of relevance not only in South Africa, but across the globe. Its relevance lies in the challenge of abandoning economic and political processes that violate the human right to life; it urges us to embrace the needs of the poor and the vulnerable as our "preferential option" (Gutierrez 1973, xxv-xxuiii). In this context, the "face" of human suffering and human vulnerability will hopefully appear and rise above the imperatives of a political economy that still yearns for the comforts of white society, and still seeks to reduce the possibility of being-human-in-the-world to the materialist trappings and values of neoliberal global capitalism. In the final analysis, Biko's philosophy of Black Consciousness urges us to become the "co-authors of a normal society where man is nothing else but man for his own sake" (Biko 1987, 21).

\section{References}

Alexander, Neville. 2013. Thoughts on the New South Africa. Auckland Park: Jacana.

Arendt, Hannah. 1958. The Origins of Totalitarianism. Cleveland, New York: The World Publishing Company.

Arendt, Hannah. 1968. Men in Dark Times. New York: Harcourt, Brace \& World, INC.

Berkowitz, Roger. 2010. "Introduction: Thinking in Dark Times.” In Thinking in Dark Times: Hannah Arendt on Ethics and Politics, edited by Roger Berkowitz, J. Katz and T. Keenan, 3-14. New York: Fordham University Press. https://doi.org/10.5422/fso/9780823230754.003.0001.

Biko, Steve. 1987. Steve Biko: 1946-1977. I Write What I Like. A Selection of his Writings. Edited by Aelred CR Stubbs. Johannesburg: Heinemann. 
Cloete

Bulhan, Hussein Abdilahi. 1985. Frantz Fanon and the Psychology of the Oppressed. New York, London: Plenum Press. https://doi.org/10.1007/978-1-4899-2269-4.

Du Bois, W.E.B. 2007. The Souls of Black Folk. New York: Oxford University Press.

Dussel, Enrique. 2013. Ethics of Liberation: In the Age of Globalization and Exclusion. Durham, London: Duke University Press. https://doi.org/10.1515/9780822395218.

Elphick, Richard, and V. C. Malherbe. 1989. "The Khoisan to 1828.” In The Shaping of South African Society, 1652-1840, edited by Richard Elphick and Herman Giliomee, 3-65. Cape Town: Maskew Millar Longman.

Fanon, Frantz. 2017. Black Skin, White Masks. London: Pluto Press.

Gibson, Nigel C. 2008. "Black Consciousness after Biko: The Dialectics of Liberation in South Africa, 1977-1987.” In Biko Lives! Contesting the Legacies of Steve Biko, edited by Andile Mngxitama, Amanda Alexander and Nigel C. Gibson, 129-155. New York: Palgrave Macmillan. https://doi.org/10.1057/9780230613379_8.

Giroux, Henry A. 2018. American Nightmare: Facing the Challenge of Fascism. San Francisco: City Lights Books/Open Media Series.

Gray, John. 1998. False Dawn: The Delusions of Global Capitalism. London: Granta Books.

Gutierrez, Gustavo. 1973. A Theology of Liberation: History, Politics, and Salvation. New York: Orbis Books.

Gyekye, Kwame. 2002. "Person and Community in African Thought." In Philosophy from Africa: A Text with Readings, edited by P. H. Coetzee and A. P. J. Roux, 297-312. Cape Town: Oxford University Press.

Marais, Hein. 2001. South Africa: Limits to Change. The Political Economy of Transition. Cape Town: University of Cape Town Press.

Marcuse, Herbert. 1964. One-dimensional Man. Boston: Beacon Press.

Marx, Karl. 1978. "Economic and Philosophic Manuscripts of 1844.” In The Marx-Engels Reader, edited by Robert C. Tucker, 66-125. New York: W.W. Norton \& Company, INC.

Mbeki, Moeletsi. 2009. Architects of Poverty. Johannesburg: Picador Africa.

Moodley, Strini. 2008. "Interview with Strini Moodley." In Biko Lives: Contesting the Legacies of Steve Biko, edited by Andile Mngxitama, Amanda Alexander and Nigel G. Gibson, 267-283. New York: Palgrave Macmillan. https://doi.org/10.1057/9780230613379_15. 
Cloete

Neocosmos, Michael. 2010. From "Foreign Natives" to "Native Foreigners": Explaining Xenophobia in Post-apartheid South Africa. Dakar: Council for the Development of Social Science in Africa.

Pauw, Jacques. 2017. The President's Keepers: Those Keeping Zuma in Power and out of Prison. Cape Town: Tafelberg.

Plato. 1961. "Republic." In The Collected Dialogues of Plato: Including the Letters, edited by Edith Hamilton and Huntington Cairns, translated by Paul Shorey, 575-844. Princeton, NJ: Princeton University Press.

Ramose, Mogobe B. 1999. African Philosophy Through Ubuntu. Harare: Mond Book Publishers.

Ramose, Mogobe B. 2002. "The Struggle for Reason in Africa.” In Philosophy from Africa, edited by P. H. Roux, and A. P. J. Coetzee, 1-8. Cape Town: Oxford University Press Southern Africa.

Samara, Tony Roshan. 2011. Cape Town after Apartheid: Crime and Governance in the Divided City. Minneapolis, London: University of Minnesota Press. https://doi.org/10.5749/minnesota/9780816670000.001.0001.

Saul, John Ralston. 2005. The Collapse of Globalism. London: Atlantic Books.

Terreblanche, Sampie. 2002. A History of Inequality in South Africa. 1652-2002. Pietermaritzburg: University of Natal Press. 